\title{
ALTERNATIF PENYELESAIAN SENGKETA SECARA ARBITRASE MELALUI PEMANFAATAN TEKNOLOGI INFORMASI
}

\author{
Faisal Riza, Rachmad Abduh \\ Fakultas Hukum Universitas Muhammadiyah Sumatera Utara \\ Jl. Kapt. Mukhtar Basri Nomor 3, Medan - Sumatera Utara \\ Email: faisalriza@umsu.ac.id, rachmadabduh@umsu.ac.id
}

\begin{abstract}
Abstrak
Penyelesaian sengketa pada intinya dapat dilakukan melalui dua proses, yaitu proses litigasi di pengadilan dan non-litigasi di luar pengadilan. Secara umum, proses litigasi akan menghasilkan perjanjian permusuhan yang belum mampu merangkul kepentingan bersama karena kepentingan mereka saling berhadapan. Hasil dari proses penyelesaian sengketa di pengadilan cenderung menimbulkan masalah baru, menghabiskan waktu yang lama, membutuhkan biaya yang mahal, tidak responsif, dan menimbulkan permusuhan antara pihakpihak yang bersengketa. Melalui proses penyelesaian sengketa di luar pengadilan, itu akan menghasilkan solusi win-win agreement, kerahasiaan terjamin, terlindungi dari prosedur administrasi yang lambat, biaya rendah, hubungan baik masih akan dibangun untuk para pihak yang bersengketa. Arbitrase adalah cara untuk menyelesaikan perselisihan sipil di luar pengadilan umum. Metode penyelesaian didasarkan pada perjanjian arbitrase yang dibuat secara tertulis oleh para pihak yang bersengketa. Prasyarat utama untuk proses arbitrase adalah kewajiban para pihak yang bersengketa untuk membuat perjanjian tertulis (klausul arbitrase), dan kemudian menyetujui hukum dan prosedur untuk bagaimana mereka akan mengakhiri perselisihan. Penyelesaian arbitrase banyak digunakan dalam sengketa perdagangan. Meningkatnya perkembangan perdagangan, keuangan dan industri nasional dan internasional di era globalisasi saat ini telah menyebabkan kemajuan dalam ekonomi dan industri.
\end{abstract}

\section{Kata kunci: Penyelesaian, Sengketa, Arbitrase, Teknologi , Informasi}

\section{Abstract}

Dispute resolution in essence can be done through two processes, namely the litigation process in court and non-litigation outside the court. In general, the litigation process will produce adversial agreements that have not been able to embrace common interests because their interests are facing each other. The results of the dispute resolution process in the courts tend to cause new problems, spend a long time, require expensive, unresponsive, and cause hostility between the parties to the dispute. Through a dispute resolution process outside the court, it will result in a win-win agreement solution, guaranteed confidentiality, protected from slow administrative procedures, low costs, good relations will still be established for the parties to the dispute. Arbitration is a way to resolve civil disputes outside the general court. The method of settlement is based on an arbitration agreement made in writing by the parties to the dispute. The main prerequisite for an arbitration process is the obligation of the parties to the dispute to make a written agreement (arbitration clause), and then agree on the law and procedure for how they will end the dispute. Arbitration settlement is widely used in trade disputes. The increasing development of trade, finance and national and international industries in the current era of globalization has led to advances in the economy and industry.

Keywords: Resolution, Dispute, Arbitrase, Technology, Information 
DEIFGA LATA

Jurnal Ilmu Hukum

FAKULTAS HUKUM UMSU
Alternatif Penyelesaian Sengketa...(Faisal Riza, Rachmad Abduh )

Volume 4 Nomor 1, Januari-Juni 2019, 77-86 DOI: https://doi.org/10.30596/dll.v4i1.3171

\section{PENDAHULUAN}

Majunya teknologi informasi berdampak pada perkembangan prilaku masyarakat khususnya dalam menyelesaikan sengketa di luar pengadilan. Pemanfaatan teknologi internet sudah sedemikian banyak merambah pada bidang kehidupan masyarakat, terutama merabah kebidang hukum. Hasil survey yang dilakukan oleh Asosiasi Penyelenggara Jasa Internet Indonesia (APJII) yang dapat dilihat dalam laman statistic apjii.or.id,tercatat pada Tahun 2017 jumlah pengguna internet di Indonesia mencapai 143,26 juta jiwa. Angka tersebut meningkat disbandingkan pada tahun 2016 yang mencapai 132,7 juta jiwa.

Karena itu, pemanfaatan teknologi dalam masyarakat bukan hal yang ekslusif. Teknologi informasi sangat berperan penting dalam perdagangan dan pertumbuhan perekonomian nasional demi mewujudkan kesejahteraan masyarakat. Selain itu juga sangat berperan dalam bidang hukum untuk menunjukkan informasi penanganan dan informasi penyelesain perkara di pengadilan maupun di luar pengadilan demi mewujudkan penegakan hukum yang transparan dan tidak berbelit.

Pasal 4 Undang-Undang Nomor 11 Tahun 2008 menentukan bahwa pemanfaatan teknologi informasi dan transaksi elektronik dilaksanakan untuk meningkatkan efektivitas dan efisiensi pelayanan publik, juga memberikan rasa aman, keadilan dan kepastian hukum bagi pengguna dan penyelenggara teknologi informasi.

Pelaksanaan penyelesaian sengketa di luar pengadilan secara arbitrase melalui teknologi informasisesungguhnya dapat dilakukan.Lembaga arbitrase yang membuat putusanpun dapat melakukan tugasnya dengan baik, dan para arbiter yakinbahwa pengadilan akan mengikuti atau menjalankan putusannya. Meski keyakinan itu ada, namun terdapat kriteria tertentu (Susanti Adi Nugroho, 2015, h. 474) yang harus dipenuhi agar suatu putusan dapat dijalankan oleh pengadilan. Kriteria itu terdapat dalam konvensi internasional maupun dalam hukum nasional mengenai arbitrase. Penyelesaian sengketa secara arbitrase melalui teknologi informasi masih banyak menuai persoalan, yang persoalan ini nanti akan diteliti sebagai bahan kajian dalam penelitian ini. Persoalan itu lebih erat kaitannya dengan persoalan hukum daripada persoalan teknologinya, misalnya keabsahan perjanjian arbitrase, prosedur berarbitrase hingga putusan arbitrase.

Memang sulit untuk membicarakan masalah hukum dalam dunia teknologi (internet) yang semakin berkembang ini, terutama dalam membahas penyelesaian sengketa secara arbitrase melalu teknologi informasi (internet). Namun tentunya akan ada suatu solusi dan dasar hukum yang melegalkan perbuatan tersebut (menyelesaikan sengketa). Arbitrase merupakan cara untuk menyelesaikan sengketa perdata di luar pengadilan umum. Cara penyelesaian tersebut didasarkan pada perjanjian arbitrase yang dibuat secara tertulis oleh para pihak yang bersengketa. Prasyarat yang utama bagi suatu proses arbitrase yaitu kewajiban para pihak yang bersengketa untuk membuat suatu kesepakatan tertulis (arbitration clause), dan kemudian menyepakati hukum dan tata cara bagaimana mereka akan mengakhiri sengketanya. 
Alternatif Penyelesaian Sengketa...(Faisal Riza, Rachmad Abduh )

Volume 4 Nomor 1, Januari-Juni 2019, 77-86 DOI: https://doi.org/10.30596/dll.v4i1.3171

Di dalam perkembangannya, arbitrase belum juga mampu memenuhi kebutuhan yang semula diharapkan mudah dan cepat dalam proses penyelesaian. Penumpukan kasus sengketa dan cara penyelesaian yang harus bertemu langsung kini mengalami kontraksi yang cenderung formalistik meniru pola litigasi. Padahal perkembangan teknologi informasi (internet) dapat dimanfaatkan dalam penyelesaian sengketa tersebut.

Upaya penyelesaian sengketa secara arbitrase melaluiteknologisudah mulai dikenal dan diberlakukan di negara-negara maju seperti Amerika, Inggris, Kanada dan beberapa negara di Eropa. Cara penyelesaian sengketa ini sangat menarik karena dilakukan secara online sehingga memudahkan para pihak untuk menyelesaikan sengketa dimanapun mereka berada tanpa terhalang waktu dan tempat. Di Indonesia arbitrase seperti ini merupakan hal baru dan belum diatursecara rincidalam suatu peraturan khusus(Solikhah, 2009, h. 22).Sehingga arbitrase online tersebut hampir sama dengan arbitrase konvensional, perbedaannyadalam arbitrase online proses pendaftaran perkara, pemilihan arbiter, pembuatan putusan, penyerahan dokumen, permusyawaratan arbitrator, serta pemberitahuan akan adanya putusan dilakukan secara online.

Meski masih mempunyai kelemahan, penyelesaian sengketa secara arbitrase melalui teknologi informasi dianggap sebagai solusi yang baik dalam menyelesaikan sengketa dibandingkan dengan cara konvensional oleh para pelaku bisnis.Dampak perkembangan teknologi informasi memberikan kemudahan terhadap proses penyelesaian sengketa, karena dokumen perkara dapat ditransmisikan secara lebih cepat kepada arbiter dengan biaya yang lebih ringan. Penyelesaian Sengketa secara Arbitrase dapat dilakukan melalui sarana elektronik atau dalam bentuk sarana komunikasi lainnya yang disepakati oleh para pihak agar keabsahannya terjamin. Hal tersebut dinyatakan dalam Pasal 4 ayat 3 Undang-Undang Nomor 30 Tahun 1999 tentang Arbitrase dan Alternatif Penyelesaian Sengketa. Karena itu, penelitian mengenai Alternatif Penyelesaian Sengketa di Luar Pengadilan Melalui Pemanfaatan Teknologi Informasi penting untuk dilakukan.

Berdasarkan uraian di atas maka dapat ditarik permasalahan yang akan diteliti yaitu tentang bagaimana alternative penyelesaian sengketa secara arbitrase melalui pemanfaatan teknologi informasi dan apa kelebihan, kekurangan dan hambatan dalam menyelesaikan sengketa secara arbitrase melalui pemanfaatan teknologi informasi.

\section{METODE PENELITIAN}

Metode yang digunakan dalam penelitian ini adalah metode kualitatif, dengan pendekatan penelitian deskriptif yang dilakukan dengan cara mendeskripsikan (menggambarkan/ menceritakan) kembali secara tertulis dari hasil observasi dan wawancara lapangan tentang penyelesaian sengketa secara arbitrase melalui pemanfaatan teknologi informasi. Berdasarkan cara memperoleh datanya, maka penelitian ini termasuk ke dalam jenis penelitian lapangan (field research), karena peneliti langsung terlibat dengan arbiter dan mendalami hambatan yang terjadi khususnya tentang arbitrase. Data diperoleh melalui: observasi, wawancara, dan dokumentasi. 
Jurnal Ilmu Hukum

FAKULTAS HUKUM UMSU
Alternatif Penyelesaian Sengketa...(Faisal Riza, Rachmad Abduh )

Volume 4 Nomor 1, Januari-Juni 2019, 77-86 DOI: https://doi.org/10.30596/dll.v4i1.3171

Penelitian yang akan dilakukan berawal dari rumusan masalah dalam lingkup peristiwa yang sedang atau terus terjadi, dan bisa juga diamati serta diverifikasi secara nyata pada saat berlangsungnya penelitian. Peristiwa-peristiwa yang diamati termasuk dalam konteks kegiatan orang-orang dalam hal ini para pihak yang bersengketa, dan arbiter yang menyelesaikan sengketa tersebut. Sesuai dengan rumusan masalah yang diangkat dalam penelitian ini, maka dipilih lokasi penelitian di Badan Penyelesaian Sengketa Konsumen (BPSK) Kota Medan, berkantor di Jalan Persatuan Nomor 3 STM Kampung Baru Medan.

Peneliti sebagai ujung tombak mengumpulkan data (instrumen) dalam penelitian kualitatif. Peneliti secara langsung ke lapangan untuk mengumpulkan sejumlah informasi yang dibutuhkan. Dalam rangka kepentingan pengumpulan data, teknik yang digunakan berupa kegiatan observasi di Badan Penyelesaian Sengketa Konsumen (BPSK) Kota Medan, wawancara dan studi dokumentasi. Peneliti harus mampu memahami dan berinteraksi dengan subjek penelitian secara langsung. Menyesuaikan sikap dan penampilan dengan kebiasaan dan tata cara melakukan penelitian. Peneliti bertindak netral dengan berperan dalam kegiatan penelitian dan menjaga hubungan yang akrab dengan subjek. Jika hal itu tidak dilakukan maka peneliti akan kesulitan mendapatkan informasi yang diperlukan. Wawancara di sekretariat Badan Penyelesaian Sengketa Konsumen (BPSK) Kota Medan dengan beberapa orang dari pihak yang bersengketa dan arbiter yang menyelesaikan sengketa.

Observasi atau pengamatan dilakukan pada saat proses awal sampai akhir penyelesaian sengketa di ruang sidang Badan Penyelesaian Sengketa Konsumen (BPSK) Kota Medan. Studi dokumentasi akan dilakukan oleh peneliti untuk mendukung argumentasi dan pendapatpendapat hukum yang terkait dengan alternatif penyelesaian sengketa secara arbitrase melalui teknologi informasi di Badan Penyelesaian Sengketa Konsumen (BPSK) Kota Medan. Untuk mengolah data yang didapat, peneliti menggunakan metode deskriftif analitis. Pemaparan tentang teori-teori yang telah dikemukakan, akan memudahkan peneliti mengambil beberapa hal yang dapat dijadikan kesimpulan dalam pembahasan.

Peneliti akan melakukan penyajian data atau sekumpulan informasi yang tersusun yang akan memberi kemungkinan adanya penarikan suatu kesimpulan. Hal ini dimaksudkan agar data-data yang diperoleh selamaproses penelitian dapat dibuat dalam bentuk naratif, sehingga perlu penyederhanaan data atau informasi tanpa mengurangi isinya.

Peneliti akan mengutarakan kesimpulan dari data-data yang telah diperoleh. Hal ini bermaksud untuk mencari makna data yang dikumpulkan dengan menelusuri hubungan, persamaan, atau perbedaan.Penarikan kesimpulanjuga akan dilakukan oleh peneliti dengan cara membandingkan kesesuaian pernyataan dari subyek penelitian dengan makna yang terkandung dengan konsep-konsep dasar dalam penelitian ini.

\section{PEMBAHASAN}

\section{Alternatif Penyelesaian Sengketa Secara Arbitrase Melalui Pemanfaatan Teknologi Informasi}

Konsepsi pemikiran bahwa hukum merupakan salah satu sarana pembaruan dan pembangunan masyarakat sudah diterima di Indonesia. Hukum sebagai sarana pembaruan 
Alternatif Penyelesaian Sengketa...(Faisal Riza, Rachmad Abduh )

Volume 4 Nomor 1, Januari-Juni 2019, 77-86 DOI: https://doi.org/10.30596/dll.v4i1.3171

masyarakat adalah keharusan mutlak, karena merupakan penjelmaan dari keinginan masyarakat dalam usaha pembangunan dan pembaruan demi terjaganya ketertiban dan keteraturan. Di sisi lain, hukum sebagai sarana pembangunan merupakan penyalur arah kegiatan manusia sebagaimana yang dikehendaki oleh pembaruan tersebut (Mochtar Kusumaatmadja, 1986, h. 88).

Di dalam hal ini, bagian dari pembaruan dan pembangunan bidang bisnis Indonesia adalah melalui sarana penyelesaian sengketa. Hal ini kemudian mendorong terbentuknya pengaturan penyelesaian sengketa bisnis yang lebih cepat, dan kemudian pada tahun 1999 disahkan Undang-Undang Nomor 30 Tahun 1999 tentang Arbitrase dan Alternatif Penyelesaian Sengketa yang membuka lebar-lebar kesempatan untuk menyelesaikan perkaraperkara bisnis di luar pengadilan.

Aktifitas perdagangan suatu negara menjadi indikasi tingkat kemakmuran masyarakatnya serta menjadi tolak ukur tingkat perekonomian negara itu sendiri, sehingga dapat dikatakan bahwa perdagangan merupakan urat nadi perekonomian suatu negara. Peran perdagangan dalam suatu wilayah sangat penting, baik perdagangan domestik maupun perdagangan antar negara (perdagangan internasional) yang peranannya terlihat menonjol dalam pembangunan ekonomi (T.Gilarso, 2004, h. 57).

Asosiasi Penyelenggara Jasa Internet Indonesia (APJII) memproyeksikan bahwa pada tahun 2015 pengguna internet di Indonesia mencapai \pm 139 juta pengguna. Dengan angka tersebut dapat kita perkirakan jika saja 30\% dari pengguna internet di Indonesia melakukan transaksi perdagangan secara elektronik (e-commerce) maka angka yang muncul yaitu \pm 42 juta pengguna akan melakukan transaksi perdagangan. Angka ini pun apabila diperkirakan $10 \%$ transaksi berpeluang terjadi sengketa maka $\pm 4,2$ juta kasus sengketa akan muncul dan perlu diselesaikan dengan cepat, efektif, dan efisien dengan pertimbangan bahwa pihak yang bersengketa dipisahkan oleh letak geografis yang cukup jauh.

Penyelesaian sengketa yang lambat dan rumit merugikan para pencari keadilan dalam segala aspek, terlebih dalam dunia bisnis, maka akan mengakibatkan ekonomi biaya tinggi, serta dapat menguras potensi serta sumber daya perusahaan. Sementara dalam dunia bisnis sangat diperlukan penyelesaian sengketa yang cepat, biaya murah, serta informal procedure.

Mengingat telah munculnya e-commerce yang dimaksudkan untuk meniadakan kesulitan-kesulitan dalam transaksi bisnis yang konvensional, maka model penyelesaian sengketa melalui peradilan tidak diharapkan untuk dilakukan, karena hanya akan membuang waktu dan biaya. Untuk sekedar perbandingan, penyelesaian sengketa di tingkat pengadilan negeri berkisar enam bulan, di tingkat pengadilan tinggi berkisar satu tahun. Di tingkat Mahkamah Agung, tidak ada patokan waktu yang pasti untuk penyelesaian perkara. Umumnya diselesaikan dalam waktu tiga sampai empat tahun (Meria Utama, 2010:1836).

Penyelesaian sengketa elektronik (e-commerce) pada dasarnya termasuk ke dalam ranah hukum perjanjian sehingga berlaku asas kebebasan berkontrak, artinya para pihak bebas melakukan pilihan hukum dan pilihan forum penyelesaian sengketa yang akan dipakai apabila terjadi sengketa keperdataan diantara mereka. Kemudian dengan berkembangnya cara 
Jurnal Ilmu Hukum

FAKULTAS HUKUM UMSU
Alternatif Penyelesaian Sengketa...(Faisal Riza, Rachmad Abduh )

Volume 4 Nomor 1, Januari-Juni 2019, 77-86 DOI: https://doi.org/10.30596/dll.v4i1.3171

penyelesaian sengketa melalui teknologi dan komunikasi, maka penyelesaian sengketa yang terjadi dalam hal keadaan geografis terpisah bukan menjadi penghalang lagi.

Di dalam Pasal 1 angka 10 Undang-Undang Nomor 30 Tahun 1999 tentang Arbitrase dan Alternatif Penyelesaian Sengketa, mengatur pola-pola penyelesaian sengketa di luar pengadilan, sesuai dengan perkembangan zaman yang mengalami modernisasi. Jika dilihat dari praktek perdagangan bisnis sekarang ini, maka pola-pola penyelesaian sengketa di luar pengadilan tersebut dapat dikembangkan sehingga memberikan peluang adanya alternatif penyelesaian sengketa secara online.

Konsep Online Dispute Resolution dalam Undang-Undang Nomor 11 Tahun 2008 tentang Informasi dan Transaksi Elektronik ada karena adanya urgensi pemikiran tentang pentingnya pengaturan praktek kontrak elektronik di Indonesia (Hendra Atmadja, 2009, h. 67). Indonesia juga dapat dikatakan mendukung pembentukan Online Dispute Resolution didasarkan atas klausul yang disebutkan didalam ketentuan Pasal 41 Undang-Undang Nomor 11 Tahun 2008 tentang Informasi dan Transaksi Elektronik, yaitu:

a. Masyarakat dapat berperan meningkatkan pemanfaatan teknologi informasi melalui penyelenggaraan sistem elektronik dan transaksi elektronik.

b. Peran masyarakat sebagaimana pada ayat (1) dapat diselenggarakan melalui lembaga yang dibentuk oleh masyarakat.

c. Lembaga sebagaimana ayat (2) dapat memiliki fungsi konsultasi dan mediasi.

Berdasarkan Pasal 41 ayat 1 Undang-Undang Nomor 11 Tahun 2008 tersebut, menyebutkan bahwa masyarakat dapat berperan untuk meningkatkan pemanfaatan teknologi yang dapat diselenggarakan melalui lembaga yang dibentuk oleh masyarakat, sebagaimana disebutkan dalam ayat 2. Kemudian Pasal 41 ayat 3 Undang-Undang Nomor 11 Tahun 2008 tersebut, terlihat bahwa Indonesia mendukung adanya pembentukan ODR sebagai sebuah lembaga yang memiliki fungsi konsultasi dan mediasi.

Berdasarkan penjelasan Pasal 41 ayat 2 Undang-Undang Nomor 11 Tahun 2008, yang dimaksud dengan "lembaga yang dibentuk oleh masyarakat" merupakan lembaga yang bergerak di bidang teknologi informasi dan transaksi elektronik. Ini berarti tidak menutup kemungkinan untuk masyarakat membuat lembaga yang berfungsi untuk menyelesaikan sengketa secara online. Tidak hanya memiliki fungsi konsultasi dan mediasi, namun juga fungsi arbitrase yang akan dilakukan secara online. Terlihat bahwa Indonesia mendukung adanya pembentukan Online Dispute Resolution sebagai sebuah lembaga dalam hal penyelesaian sengketa (Andi Julia, 2015, h. 176)

Mengenai upaya penyelesaian sengketa transaksi elektronik diatur dalam Pasal 18 ayat 4 Undang-Undang Nomor 11 Tahun 2008 tentang Informasi dan Transaksi Elektronik, yang menyebutkan: (1) Transaksi elektronik yang dituangkan ke dalam kontrak elektronik mengikat para pihak; (2) Para pihak memiliki kewenangan untuk memilih hukum yang berlaku bagi transaksi internasional yang dibuatnya; (3) Jika para pihak tidak melakukan pilihan hukum dalam transaksi elektronik internasional, hukum yang berlaku didasarkan pada asas hukum perdata internasional; (4) Para pihak memiliki kewenangan untuk menetapkan 
DEIFGA LATA

Jurnal Ilmu Hukum

FAKULTAS HUKUM UMSU
Alternatif Penyelesaian Sengketa...(Faisal Riza, Rachmad Abduh )

Volume 4 Nomor 1, Januari-Juni 2019, 77-86 DOI: https://doi.org/10.30596/dll.v4i1.3171

forum pengadilan, arbitrase, atau lembaga penyelesaian sengketa alternatif lainnya yang berwenang menangani sengketa yang mungkin timbul dari transaksi elektronik internasional yang dibuatnya; (5) Jika para pihak tidak melakukan pilihan forum sebagaimana dimaksud dalam ayat (4), penetapan kewenangan pengadilan, arbitrase, atau lembaga penyelesaian sengketa alternatif lainnya yang berwenang menangani sengketa yang mungkin timbul dari transaksi tersebut, didasarkan pada asas hukum internasional (OK. Saidin, 2015, h. 265).

Pada dasarnya, Online Dispute Resolution (ODR) sama seperti penyelesaian sengketa konvensional lainnya, perbedaannya terletak pada medianya yang menggunakan media Internet (International Network). ODR termasuk ke dalam Alternative Dispute Resolution (ADR), dimana ADR memiliki 3 (tiga) tipe penyelesaian sengketa, yaitu negosiasi, mediasi dan arbitrase (I Made Widnyana, 2014, h. 47).

Prosedur untuk menyelenggarakan arbitrase melalui pemanfaatan teknologi informasi sebagai berikut: (Susanti Adi Nugroho, 2015, h. 43)

a. Peraturan yang diperlukan mengenai permohonan untuk berarbitrase dan pelaksanannya (hal ini meliputi juga peraturan yang diterapkan oleh badan arbitrase tersebut dan informasi yang disediakan);

b. Menyediakan cara untuk memilih arbiter, menerima tempat kedudukan atau menolaknya;

c. Menyediakan tata cara berarbritase seperti penyediaan peraturan prosedural seperti tata cara mengajukan perkara secara online, menyampaikan tanggapan, mengajukan bukti-bukti dan argumentasi, dan kemungkinan adanya penundaan;

d. Penyediaan tata cara penggunaan pesan secara elektronik, seperti penyelenggaraan prosedur yang hanya menggunakan dokumen elektronik, penggunaan video conferencing dan audio conferencing termasuk dalam hal ini penyediaan alat-alat bukti berupa keterangan saksi dan saksi ahli.

e. Penyediaan pembuatan putusan secara online dan persyaratan yang diperlukan agar suatu putusan dapat diterima dan dijalankan. Penyediaan prosedur yang mungkin untuk mengadakan perlawanan atau banding terhadap putusan. Penyediaan prosedur yang dapat memungkinkan proses berjalan secara rahasia dengan menyediakan teknologi enkripsi dan tanda tangan elektronik;

f. Penyediaan sarana untuk penyimpanan data terutama dalam perlawanan menyangkut hak dari salah satu pihak untuk melakukan perlawanan karena adanya dugaan bahwa hak-hak dari salah satu pihak telah dilanggar.

Pada dasarnya, penyelesaian sengketa secara arbitrase melalui pemanfaatan teknologi informasi sangat baik diterapkan. Namun di Badan Penyelesaian Sengketa Konsumen belum menerapkan penyelesaian sengketa secara online. Sengketa yang ada di BPSK Medan diselesaikan secara mediasi dan arbitrase manual. Pelaksanaan mediasi dan arbitrase dilakukan secara manual yaitu dengan cara bertemu langsung para pihak dengan mediator atau arbiter. Ruangan pelaksanaan mediasi atau arbitrase sudah dipersiapkan, para pihak dipanggil untuk hadir ke ruang mediasi atau arbitrase.

Hampir setiap tahun BPSK Medan menerima perkara sengketa antara Konsumen dengan Pelaku Usaha. Rata-rata per tahun sebanyak 90 perkara, pada tahun 2019 ini sejak 
Jurnal Ilmu Hukum

FAKULTAS HUKUM UMSU
Alternatif Penyelesaian Sengketa...(Faisal Riza, Rachmad Abduh )

Volume 4 Nomor 1, Januari-Juni 2019, 77-86 DOI: https://doi.org/10.30596/dll.v4i1.3171

bulan januari hingga April perkara yang masuk ada 57 perkara. Dari 57 perkara itu 40\% diselesaikan secara mediasi $60 \%$ diselesaikan secara arbitrase. Agar terjadi percepatan dalam penyelesaian sengketa, sebaiknya dilakukan secara online dengan memanfaatkan teknologi sebagai sarananya.

Prosedur untuk berarbitrase secara online dapat dilakukan berdasarkan ketentuan dalam Pasal 4 ayat 3 Undang-Undang Arbitrase dan Alternatif Penyelesaian Sengketa yang menentukan dalam hal disepakati penyelesaian sengketa melalui arbitrase terjadi dalam bentuk pertukaran surat, maka pengiriman teleks, telegram, faksimili, e-mail, atau dalam bentuk sarana komunikasi lainnya, wajib disertai dengan suatu catatan penerimaan oleh para pihak.

Berdasarkan hal tersebut, penyelenggaraan arbitrase online dimungkinkan apabila ada kesepakatan terlebih dahulu dari para pihak untuk menyelenggarakan arbitrase secara online. Secara online dapat dimaknai bahwa pelaksanaan penyelesaian sengketa dilakukan menggunakan alat teknologi informasi.

\section{Kelebihan, Kekurangan Dan Hambatan Dalam Menyelesaian Sengketa Secara Arbitrase Melalui Pemanfaatan Teknologi Informasi}

Mengingat proses penyelesaian sengketa tergolong lambat dan rumit yang berakibatkan kerugian para pencari keadilan dalam segala aspek, terlebih dalam dunia bisnis, maka konsep penyelesaian sengketa secara arbitrase melalui pemanfaatan teknologi informasi sangat diharapkan, keefektifitasan dalam penyelesaian sengketa secara arbitrase melalui pemanfaatan teknologi informasi ini diakui lebih cepat dan hemat biaya jika dibandingkan dengan model penyelesaian sengketa di pengadilan karena hanya akan membuang waktu dan biaya. Untuk sekedar perbandingan, penyelesaian sengketa di tingkat pengadilan negeri berkisar enam bulan, di tingkat pengadilan tinggi berkisar satu tahun. Di tingkat Mahkamah Agung, tidak ada patokan waktu yang pasti untuk penyelesaian perkara. Umumnya diselesaikan dalam waktu tiga sampai empat tahun.

Meskipun terdapat beberapa kelebihan dalam penyelesaian sengketa secara arbitrase melalui pemanfaatan teknologi informasi, proses penyelesaian sengketa ini juga terdapat kekurangan. Penyelesaian Sengketa secara online membutuhkan perangkat teknologi informasi, khususnya internet untuk proses penyelesaian sengketa. Perangkat teknologi informasi yang digunakan memiliki jaringan internet yang baik sehingga dapat memproses infomasi dan diteruskan kepada pihak-pihak yang terlibat dalam penyelesaian sengketa (Adel Chandra, 2014, h. 81). Sebagaimana sebelumnya disebutkan bahwa ODR adalah penyelesaian sengketa dilakukan dengan menggabungkan informasi pengolahan teknologi komputer dengan fasilitas jaringan komunikasi internet, mengingat Indonesia termasuk Negara yang memiliki jaringan internet terburuk maka proses penyelesaian sengketa ini sulit diterapkan.

Online Dispute Resolution (ODR) memerlukan pra syarat tertentu agar dapat diterapkan di Indonesia. Namun untuk saat ini, terdapat beberapa kendala yang dapat menghambat ODR dalam penyelesaian sengketa di Indonesia, diantaranya adalah: (Meline Gerarita Sitompul, 2016, h. 90). 
Alternatif Penyelesaian Sengketa...(Faisal Riza, Rachmad Abduh )

Volume 4 Nomor 1, Januari-Juni 2019, 77-86 DOI: https://doi.org/10.30596/dll.v4i1.3171

a. Aturan hukum belum jelas

Belum adanya aturan hukum untuk mengajukan perkara/sengketa melalui sistem online. Akibatnya akan menimbulkan kebingungan bagaimana seharusnya para pihak akan mengajukan gugatan, melalui instrument apa data-data mereka dapat dikirimkan, dan bagaimana perlindungan hukum terhadap kerahasiaan data para pihak. Maka dari itu, perlu adanya penguatan terhadap aturan perundang-undangan terkait dengan ODR ini.

b. Lembaga belum tersedia

Jika di Amerika sudah terdapat lembaga yang menangani ODR yaitu AAA (American Arbitration Association) dan China memiliki CIETAC (China International Economic and Trade Arbitration Commision), Indonesia sendiri belum memiliki institusi khusus atau divisi dan sejenisnya baik yang berdiri sendiri ataupun dibawah pengawasan Badan Arbitrase Nasional Indonesia (BANI) yang menangani secara khusus melalui mekanisme online, termasuk mekanisme persidangan. Para pihak boleh mengirimkan dokumen secara tertulis melalui email, tetapi untuk mekanisme sidang secara online, penyerahan data online yang bisa dibaca secara bersamaan oleh para pihak bersama majelis arbiter ataupun mediator belum dapat dilakukan.

c. Perangkat website yang belum tersedia

Di Indonesia, belum menyiapkan peraturan, perangkat software, laman khusus atau website khusus untuk mengelola sengketa secara online seperti yang terdapat di negara Amerika (www.adr.org) dan China (www.cietac.org) misalnya dengan standar keamanan yang ketat. Aspek teknologi dalam keberlakuan ODR juga memegang peranan penting, dimana teknologi berkaitan dengan keamanan dalam pelaksanaan ODR.

\section{KESIMPULAN DAN SARAN}

\section{Kesimpulan}

Alternatif Penyelesaian Sengketa Secara Arbitrase Melalui Pemanfaatan Teknologi Informasi. Pemanfaatan teknologi informasi dalam menyelesaikan sengketa secara arbitrase sangat baik dilakukan, sebab tidak ada aturan yang melarang hal tersebut. Melalui teknologi informasi dalam menyelesaikan sengketa akan meminimalisir konflik, menghemat waktu dan biaya yang dikeluarkan dalam mengurus sengketa tersebut. Kelebihan, Kekurangan dan Hambatan dalam Menyelesaian Sengketa Secara Arbitrase Melalui Pemanfaatan Teknologi InformasiMenyelesaikan sengketa secara arbitrase melalui pemanfaatan teknologi informasi memiliki kelebihan yaitu proses sederhana, biaya ringan dan waktu tidak banyak terbuang. Sedangkan kekurangannya yaitu belum ada aturan hukum yang tegas memperkuat mengenai penyelesaian sengketa seperti ini, sehingga masih menimbulkan kekhawatiran para pihak terhadap sengketanya. Hambatan yang dihadapi adalah sumber daya manusia dan perangkat pendukung untuk kegiatan tersebut belum memadai.

\section{Saran}

Sebaiknya dalam menyelesaikan sengketa secara arbitrase dimanfaatkan teknologi informasi yang berkembang saat ini, agar waktu dan biaya yang dikeluarkan dapat dihemat. 
Sebaiknya dibuat aturan hukum yang tegas untuk memperkuat mengenai penyelesaian sengketa seperti ini, agar tidak ada kekhawatiran para pihak terhadap hal tersebut. Sumber daya manusia dan perangkat pendukung untuk kegiatan tersebut harus segera dibenahi. 
Alternatif Penyelesaian Sengketa...(Faisal Riza, Rachmad Abduh ) Volume 4 Nomor 1, Januari-Juni 2019, 77-86 DOI: https://doi.org/10.30596/dll.v4i1.3171

\section{DAFTAR PUSTAKA}

Barkatullah, Abdul Halim. (2010). Penerapan Arbitrase Online dalam Penyelesaian Sengketa Transaksi E-commerce. Jurnal Hukum No. 3 Vol. 17 Juli.

Haley, Nolan., \& M. Jacqueline. (2016). Alternative Dispute Resolution. New York: West Publishing Company.

Indrani, Sarah Meilita., dkk. (2017). Keberadaan Arbitrase Online Sebagai Cara Penyelesaian Sengketa Bisnis di Indonesia (Studi di Badan Arbitrase Nasional Indonesia Jakarta). Privat Law Vol. V No 2 Juli-Desember.

Kapindha, Ros Angesti Anas., \& M. Salvatia Dwi., dkk. (2014). Efektivitas dan Efisiensi Alternative Dispute Resolution` (ADR) Sebagai Salah Satu Penyelesaian Sengketa Bisnis di Indonesia. Privat Law 12 No. 4.

Kristanto, Edwin. (2014). Peran BPSK (Badan Penyelesaian Sengketa Konsumen dalam Menyelesaikan Sengketa Konsumen Melalui Proses Mediasi di Yogyakarta. EJournal.uajy.ac.id. 6627.

Nugroho, Susanti Adi. (2015). Penyelesaian Sengketa Arbitrase dan Penerapan Hukumnya. Jakarta: Prenada Group.

Tanpongangoy, Grace Henni. (2015). Arbitrase Merupakan Upaya Hukum Dalam Penyelesaian Sengketa Dagang Internasioanal. Jurnal Lex et Societatis, III. 